\title{
ガスクロマトグラフ装置による分子抎散保数測定に対する考察*
}

\author{
新井邦 夫**.斉藤正三郎** \\ 前田 四 郎** \\ 東北大学工学部 化学工学科
}

\section{粕 畐}

円管内を居流で流れている流体中にトレーサー物質を 送入したとき，その分散状態は物筫収支により Eq. (1) であらわされる。

$$
\begin{gathered}
\frac{\partial C}{\partial \theta}=D\left(\frac{\partial^{2} C}{\partial x^{2}}+\frac{1}{r} \frac{\partial C}{\partial r}+\frac{\partial^{2} C}{\partial r^{2}}\right)-u \frac{\partial C}{\partial x} \\
\text { ただし } \quad u=2 \bar{u}\left(1-r^{2} / R^{2}\right)
\end{gathered}
$$

Taylor ${ }^{17 \sim 19)}$, Aris $^{4)}$ らは，浱度 $C$ を管断面平均浱度 $C_{\boldsymbol{m}}$, 流速 $u$ を平均流速 $\bar{u}$ でおきかえ，抬散モデルで軸 方向の分散状態をあらわし，Eq.(1) を次式で㯰き換え らることを提唱した。

$$
\begin{gathered}
\stackrel{\partial C_{m}}{\partial \theta}=E \frac{\partial^{2} C_{m}}{\partial x^{2}}-\bar{u}-\frac{\partial C_{m}}{\partial x} \\
E=D+\frac{R^{2} \bar{u}^{2}}{48 D}
\end{gathered}
$$

たたし

$$
4 l / R \gg \bar{u} R / D
$$

その後これに対して数値解 ${ }^{1)}$ あるいは実験的な面 ${ }^{3.10)}$ か ら倹討が加えられその妥当性がたしかめられた。このこ とから Eq.(3) で示される分散保数 $E$ が正確に測定され るならば,それより分子抁散保数Dが求まることになる。 近年この原理を応用して，ガスクロマトクラフ装置を利 用して比较的简䇲に $D$ を求めようとする陚みが提案され てきた9.11〜16)。すなわち Eq.(2) を $\delta$-応答に対して解く と，管の出口 $x=L$ における平均湜度 $C_{m}$ は Eq. (5) で 与えられる。

$$
\begin{gathered}
\frac{C_{m}}{\left(M / \pi R^{2} L\right)}=\frac{1}{2 \sqrt{\pi \alpha t}} e^{-(1-t)^{2} / 4 \alpha t} \\
\text { ここで } \quad \alpha=E / \bar{u} L, \quad t=\bar{u} \theta / L
\end{gathered}
$$

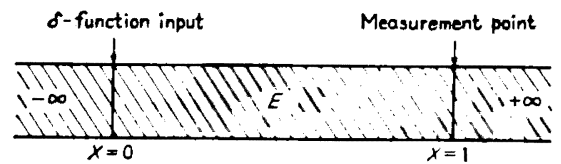

Fig. 1 Experimental scheme of an infinite tube model for determination of $D$

* <On the Determination of Gaseous Diffusion Coefficients by means of Chromatography Apparatus>

Received on May 4, 1967

** Kunjo Arai, Shozaburo Saito and Siro Maeda (Depart. ment of Chemical Engineering. Tohoku University, Sendai)
Levenspiel $ら^{(6)}$ によば

$$
a<10^{-2}
$$

なるときは，Eq.(5) は次の正規分布の式で近似できる ことが示されている。

$$
\frac{C_{m}}{\left(M / \pi R^{2} L\right)}=\frac{1}{2 \sqrt{\pi \alpha}} e^{-(1-t)^{2 / 4 \alpha}}
$$

そこで Eq.(7) により出口符度分布が正確に表現できる ならば非常に简単な解析で $D$ を求めることができる。

しかし Eq.(7) は Fig.1で示すよ 5 に混合状態すな

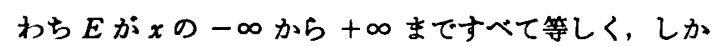
も $\delta$-応答が正確に再現されたときにのみ成立するるの である。このよ 5 な仮定は央倹的には test sectionの 長さを十分長くすることなどで近似的には满足させ $5 る$ とみなされるが，Dを求める場合はその適用条件を正確 に把握しておく必要がある。ところでガスクロ装居によ り $D$ を湘定する祭に問題となる主な因子として次の点が あげられる。すなわら 1）試料ガスの容䅪，2）試料注 入簓所ならびに検知器内における乱れ，3）管暨の粗さ, 4）管をコイル状にした軥合などの影整である。したが ってここでは主としてこれらの点に対して検討を加え, ガスクロ装膡によるDの湘定条件を明確にしよ5とする ものである。

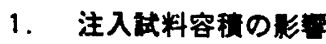

試料注入状態をठ゙閔であらわすことができるなら ば、解析は非常に简単であるが,このような注入条件を満 足させることは困難である。一般に試料の注入時間また

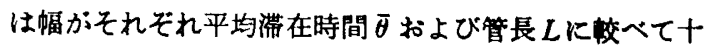
分短いときは一応る-関数とみなすことができるとされ ている。しかし精度よくDを求めるためにはそれを詳細 に㭘討しておく必要がある。valve typeの試料注入器3)

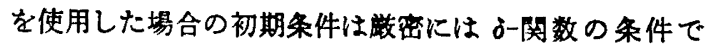
なく次の矩形波ハルスの条件を使用する方がのぞまし wo

$$
\left.\begin{array}{ll}
|x|<l_{l} / 2 & C_{m}=C_{0} \\
|x| \geq l_{l} / 2 & C_{m}=0
\end{array}\right\} \text { at } \theta=0
$$

Eq. (2) を Eq. (8) のもとに解くと $x=L$ における港度 
分布は周知のことく次の Eq.(9) で与えられる。

$$
\begin{aligned}
& \frac{C}{C_{0}}=\frac{1}{2}\left\{\operatorname{erf}\left(\frac{\frac{1}{2} \beta-1+t}{2 \sqrt{\alpha t}}\right)+\operatorname{erf}\left(\frac{\frac{1}{2} \beta+1-t}{2 \sqrt{\alpha t}}\right)\right\} \\
& \text { たたし } \quad \beta=l_{\mathrm{i}} / L
\end{aligned}
$$

ところが Eq. (9) から $\alpha$ すなわち $E$ を求める方法は Eq. (7) の正規分布の式と比較して非常に煩雑となるし, また一般にl、を正確に決めることも困難である。した がって Sample 幅すなわち試料 容積が無視できる範囲で実験を行 ならことが望ましい。以上のこと より Eq.(9) の代りに Eq. (7) か; 適用できる籍囲を明確にしておく 必要がある。

ところで筧度分布曲線が正規分 布とみなせる場合は、ピーク幅い (Fig. 2 参照) は $\alpha$ と炊のよ5な 関保にある*。

$$
\alpha=W^{2} / 32
$$

そこでいま商当な $\alpha, \beta$ を定めて Eq. (9)のビーク楅 Wを数值計 算により求め,これを Eq.(10)に 代入して $a$ を求めると,これは実 祭の浱度分布を正規分布とみて求

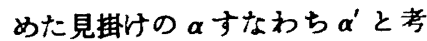
えることができる。てれでこの $\alpha^{\prime}$ より求めた分散倸数 $E^{\prime}$ の真の分 散倸数 $E$ に対する誤差は

$$
\frac{E-E^{\prime}}{E^{\prime}}=\frac{\alpha-\alpha^{\prime}}{\alpha^{\prime}}
$$

であらわすことができる。この計

算結果を Fig. 3 に示す。破線は $\beta$ を parameter とし たときの $\alpha$ の影霎を示し，細い実線は $\beta / \alpha(=l, \bar{u} / E)$ を parameter としたときのそれを示す。 $\beta$ を一定にして

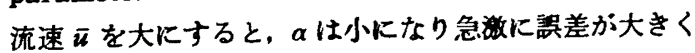
なるが，実際は $\alpha$ を大幅に小さくするには， $\bar{u}$ の変化に は制限があるので**，管長しを変えなければならない。 しかし試料注入器が与えられているような場合はいが 決ってしま5のでLを变えて $\beta$ 一定の線をたどることは できない。かかる場合は $\beta / \alpha$ 一定の線に沿って器差を 考えるくきである。また太い実線は $\delta$-応答の解 Eq.(5) を正規分布とみなした場合の潩差を示するのである。こ の㘡より

$$
B / \alpha \leq 10 \text { かつ } \alpha \leq 10^{-3}
$$
ならば $E$ の誤差は約 $0.2 \%$ 以下となり Eq. (5) および

* Fig. 2 の曲線の变曲点 $d^{2} C / d t^{2}=0$ 上り $t=1 \pm \sqrt{2 a}$, 变曲点にお。

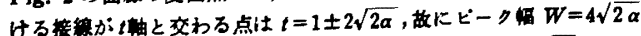

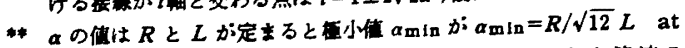
$\bar{u}=\sqrt{48} D / R$ で定まってしまい，LとRを一定にしたまま斻速 $\bar{u}$ のみで $\alpha$ を $a_{\min }$ 以下にすることはできない。

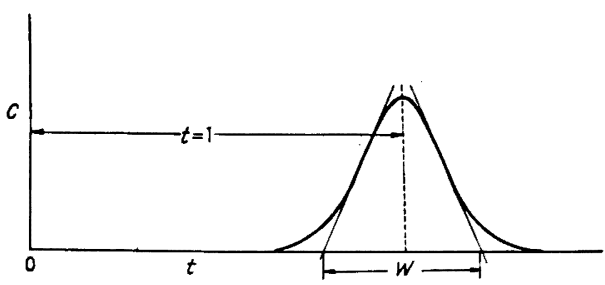

Fig. 2 Residence time distribution curve

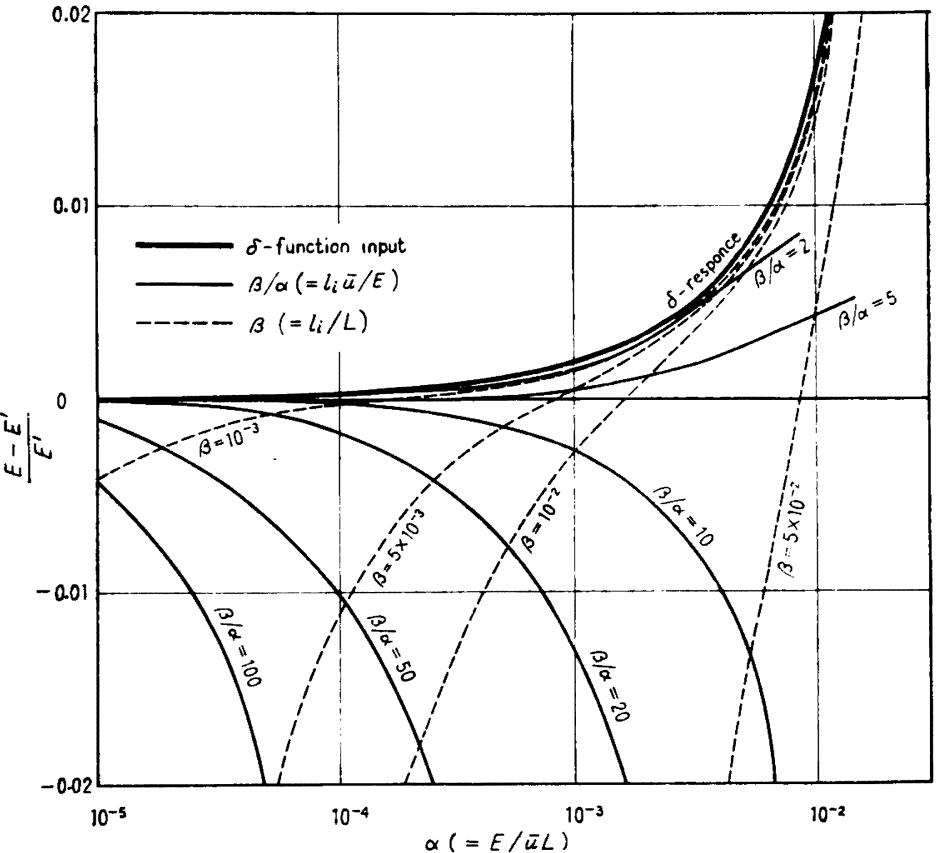

Fig. 3 Error in assuming a delta-function input

Eq.（9）を正規分布とみなしてさしつか克ないことがわ かる。

また Eq.(12)の条件は Syringe type の注入器3)を使 用した場合にる同様に適用されらることが認められ $た^{2)}$ 。

\section{2. 試料注入简所およひ模知器内における 乱れの影雾}

前節では試料注入状態が $\delta$-関数とみなしえて，かつ 滞在分布曲線 る正規分布とみなし 万る条件について検討 した。ここでは一応る一応答は満足されるとして, 陚料注 入笽所および検知器内に乱れがある場合について論ず る。すなわち Eq. (7) は分散過程に対して infinite tube

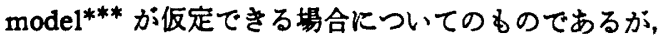

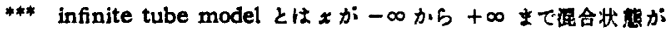

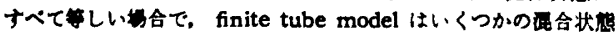
が具なる部分に分暗して考えなければならない合を称する。 


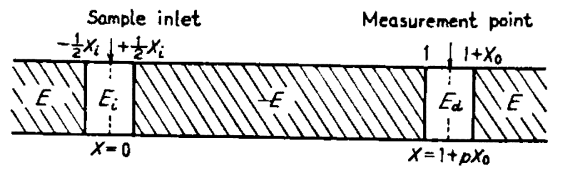

Fig. 4 Experimental scheme of a finite tube model for determination of $D$

試料注入䉪所および検知部分において，混合状態はそれ ぞれ異なるのが普通であり， finite tube model として 取り扱 5 必要がある。

finite tube model 飞対する取り扱いは Van der Laan $^{21)}$, Aris $^{(5,6)}$, Levenspiel ${ }^{(6)}$, Bischoff $5^{7,8)}$ Kより 種々の場合についてとりあげられているが，ここではこ れらと同様の手法を使用した。ガスクロ装置により払散 保数を測定する揚合は，Fig.4すなわち Eq. (13) （22） に示すよらなモデルで近似することができると考えられ る。

$$
\begin{aligned}
& \frac{\partial C_{m f}}{\partial t}+\frac{\partial C_{m f}}{\partial X}-a \frac{\partial^{2} C_{m f}}{\partial X^{2}}=0 \\
& \text { for } X \leqslant-\frac{1}{2} X_{i} \\
& \frac{\partial C_{m t}}{\partial t}+\frac{\partial C_{m t}}{\partial X}-\alpha_{i} \frac{\partial^{2} C_{m t}}{\partial X^{2}}=\delta(X) \delta(t) \\
& \text { for }-\frac{1}{2} X_{i} \leq X \leq \frac{1}{2} X_{i} \\
& \frac{\partial C_{m}}{\partial t}+\frac{\partial C_{m}}{\partial X}-\alpha \frac{\partial^{2} C_{m}}{\partial X^{2}}=0 \\
& \text { for } \frac{1}{2} X_{\imath} \leqslant X \leqslant 1 \\
& \frac{\partial C_{m d}}{\partial t}+\frac{\partial C_{m d}}{\partial X}-\alpha_{d} \frac{\partial^{2} C_{m d}}{\partial X^{2}}=0 \\
& \text { for } 1 \leqslant X \leqslant 1+X_{0} \\
& \frac{\partial C_{m 0}}{\partial t}+\frac{\partial C_{m 0}}{\partial X}-\alpha \frac{\partial^{2} C_{m 0}}{\partial X^{2}}=0 \\
& \text { for } 1+X_{0} \leq X
\end{aligned}
$$

ただ $X=x / L, \alpha_{t}=E_{t} / \bar{u} L, \quad \alpha_{d}=E_{d} / \bar{u} L$ 初期年(件 ${ }^{22}$

$$
\begin{aligned}
C_{m f}(X, 0) & =C_{m i}(X, 0)=C_{m}(X, 0) \\
& =C_{m \Phi}(X, 0)=C_{m 0}(X, 0)=0
\end{aligned}
$$

境界条(件22)

$$
\begin{gathered}
C_{m f}(-\infty, t)=\text { finite } \\
C_{m s}\left(-\frac{1}{2} X_{i}^{-}, t\right)=C_{m i}\left(-\frac{1}{2} X_{i}^{+}, t\right) \\
C_{m f}\left(-\frac{1}{2} X_{i}^{-}, t\right)-\alpha \frac{\partial C_{m f}\left(-1 / 2 X_{i}^{-}, t\right)}{\partial X} \\
=C_{m i}\left(-\frac{1}{2} X_{i}^{+}, t\right)-\alpha_{i} \frac{\partial C_{m i}\left(-1 / 2 X_{i}^{+}, t\right)}{\partial X}
\end{gathered}
$$

$$
C_{m 0}(+\infty, t)=\text { finite }
$$

$X=1 / 2 X_{i}, 1,1+X_{0}$ です Eq. (20), Eq.(21) と同粎の 境界条件がそれぞれ 2 個ずつ合計 6 個与えられる。以上
初期条件と境界条件より Eq. (13) Eq. (17) の連立敬分 方程式を解くことができるが，ここでは Van der Laan らに従い直接 $C_{m}$ 起求めす平均满在時間 $\bar{t}$ および分散度 $\sigma^{2}$ を計算することにより，検出浱度の分布の侎相を詷へ

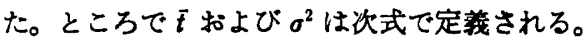

$$
\begin{gathered}
\bar{t}=\int_{0}^{\infty} t C_{m d}\left(X_{d}, t\right) d t \\
\sigma^{2}=\int_{0}^{\infty}(t-\bar{t})^{2} C_{m d}\left(X_{d}, t\right) d t
\end{gathered}
$$

たたしし $X_{d}$ は港度測定点の位貫を示す。

$$
X_{d}=1+p X_{0}^{\circ}, 0 \leqslant p \leqslant 1
$$

$\bar{t}$ および $\sigma^{2}$ は Eq.(13) (17)に Laplace 変換をほどこ せば，逆変換することなく求まり次式で与えられる。

$$
\begin{aligned}
& \bar{t}=-\left.\frac{d \bar{C}_{m d}\left(X_{d}\right)}{d s}\right|_{d \rightarrow 0} \\
& =1+p X_{0}+\alpha(a+b)-\alpha(b-1) e^{-X_{0} / 2 \alpha_{4}} \\
& -\alpha(a-1) e^{-(1-p) X_{0} / \alpha_{a}} \\
& \sigma^{2}=\left.\frac{d^{2} \bar{C}_{m a}\left(X_{d}\right)}{d s^{2}}\right|_{d \rightarrow 0}-\left.\left(\frac{d \bar{C}_{m d}\left(X_{d}\right)}{d s}\right)^{2}\right|_{a \rightarrow 0} \\
& =2 \alpha+2 \alpha a p X_{0}+\alpha(b-1) X_{1}+\alpha^{2}\left(3 a^{2}+3 b^{2}+2 a\right. \\
& +2 b-2) \\
& -4\left[\frac{1}{2} \alpha(b-1) X_{6}+\alpha^{2}\left(b^{2}-1\right)\right] e^{-x_{6} / 2 \alpha_{4}} \\
& -4\left[\alpha^{2}\left(a^{2}-1\right)+\alpha(a-1)(1-p) X_{0}\right] e^{-(1-p) x_{0} / \alpha_{a}} \\
& +2 \alpha^{2}(a-1)^{2} e^{-x_{0} / \alpha_{a}} \\
& +2 \alpha^{2}(b-1)(a-1)\left(e^{-x_{i} / \alpha_{t}}-1\right)\left(e^{-x_{0} / \alpha_{a}}\right. \\
& -1) e^{\left(x_{1} / 2-1\right) / \alpha}+\alpha^{2}(b-1)^{2} e^{-x_{1} / \alpha_{t}} \\
& -\alpha^{2}(a-1)^{2} e^{-2(1-p) X_{0} / \alpha_{\alpha}} \\
& \text { ただし } \quad \bar{C}_{m d}=\int_{0}^{\infty} C_{m d}\left(X_{d}, t\right) e^{-\lrcorner t} d t \\
& a=\alpha_{d} / \alpha, \quad b=\alpha_{t} / \alpha
\end{aligned}
$$

Eqs. (26), (27) で $a=b=1$ とすれば， $t$ および $\sigma^{2}$ は それぞれ infinite tube とみた场合の平均滞在時間 $\bar{t}_{\infty}$ および分散度 $\sigma_{\infty}^{2}$ に相当する。

$$
\begin{gathered}
\bar{t}_{\infty}=1+p X_{0}+2 \alpha_{\infty} \\
\sigma_{\infty}=2 \alpha_{\infty}\left(1+p X_{0}\right)+8 \alpha_{\infty}^{2}
\end{gathered}
$$

ここで $p=0$ すなわち浱度测定点の位值を $X_{\mathbb{4}}=1$ に扰 くと, Eqs.(28)，(29) は Levenspiel ら ${ }^{16)}$ Kより与え られたすのと一政する。

infinite tube 内の㩐度分布を表わす Eq. (7) 位ite tube に䔔用した场合に，分散俰数 $E$ に伴 5誤差の近似 的評価は次のよ5に行ならことができる。すなわち Eq. （27）に扰いて $a, b, p, X_{1}, X_{0}, \alpha$ を定めて，そのときの $\sigma^{2}$ を計算し,この $\sigma^{2}$ を $\sigma_{\infty}^{2}$ として Eq. (29) に代入して $\alpha_{\infty}$ を求める。これКよって finite tube を infinite tube とみなした场合の咀差は

$$
\frac{E-E_{\infty}}{E_{\infty}}=\frac{\alpha-\alpha_{\infty}}{\alpha_{\infty}}
$$

であらわすことができる。この計算結果の一例を Fig.5 
に示す。

Fig. 5 は港度を測定 する祭の検知器内およ び試料注入部分の乱れ がそれぞれ test section 内のそれの 5 倍, 2 倍すなわち $a=5, b$ =2 とした場合の結果 を示するので, 湜度测 定点の位圈は検知器内 で, $p=0.5$ の位置に 嘈いた場合のるのであ る。これらの曲線はそ れそれ $X_{i}, X_{0}$ を parameter として finite tube $を$ infinite tube とみた場合の $E$ に及拜 す誤差を $\alpha$ に対して plot したすのである。 ここで $X_{t}=0$ の場合 は入口の乱れを考虎し なくてるよい軥合を意

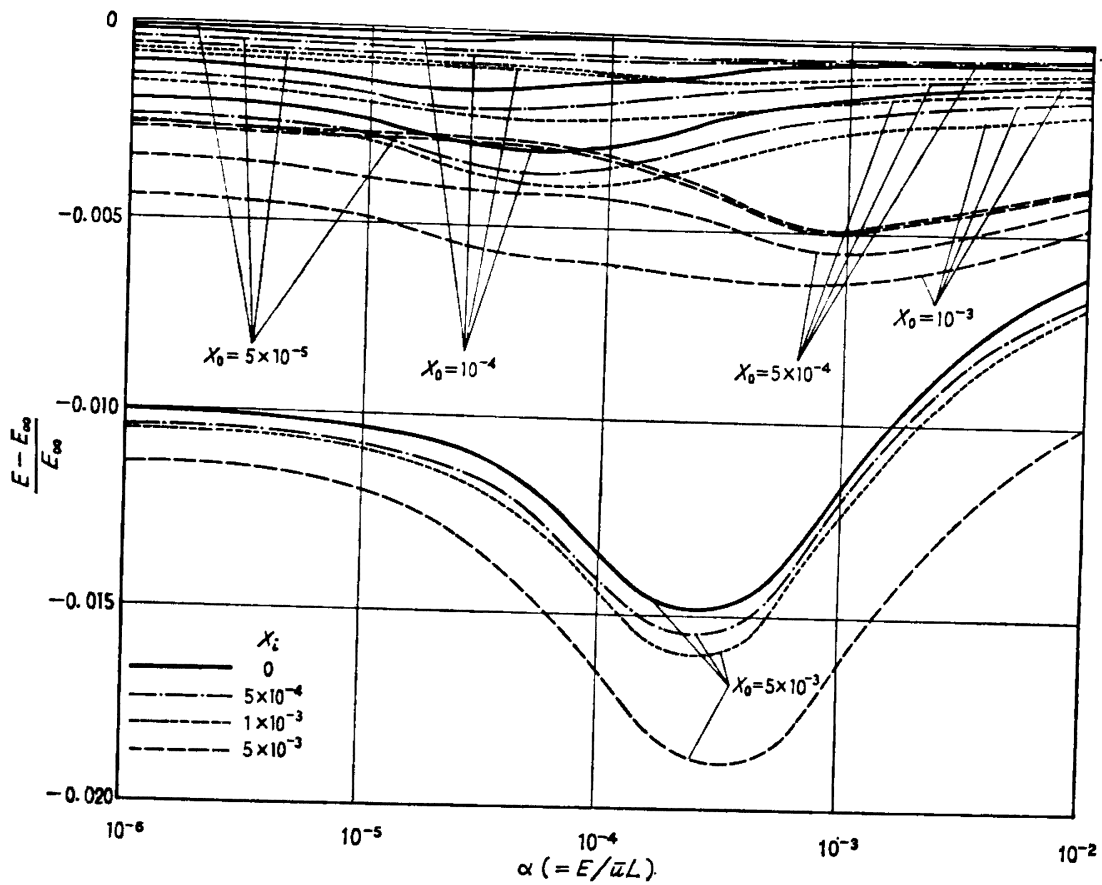

Fig. 5 Error in assuming an infinite tube for $a=5, b=2$ and $p=0.5$
味している。また $X_{i}=10^{-4}$ 程度になると $X_{i}=0$ の場合 に渐近してくることから入口の乱れはほとんど無視して よいことがわかる。ところで市㤆のガスクロマトグラフ 装置に付随する通常の分析用の検知器は, その内容積す 大きく，また通路に屈曲を有するるのが多いため, 乱れ は比較的大きいと考えられるので，Lは十分長くとる必 要がある。しかし $L$ をあまり長くとると，出口港度が希 䣋されすきて検知器の感度の限界を越ることになりかね ない。それゆえ，できれば検知器には micro cell を使 用することがのそましい。

\section{3. その他の条件}

1，2節では䈨度分布が $\delta$-応答でかつ正規分布で近似 できる操作条件の筑囲を述べたか，その他の条件として 管壁面の粗さの影繁，曲管を使用した場合の影暨などが

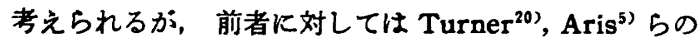
理論式により，また後者に対してはKramers ${ }^{15)}$ の実験 結果から検討を加えたがいずれる通常の実検条件であれ ばそれらの影瞥はほとんど考虔する必要のないことがみ とめられた。取後に carrier gas の最䔔流速についてで あるが，これは主として検知器の操作条件により支配さ れることは論ずるまですないか，できれば Eq.(3) の第 2 項が無視できる範囲で央験を行なうことが望ましい。 广なわら $\bar{u}$ が大になると管径の測定誤差や管断面の形 状の影鳘が大きくDの測定値に影第をおよぼす忈れがあ
るためである。このことから Eq.(3) の第 2 項が第 1 項 の 10\%以下であるような流速を選ふことが望ましい。 その条件は次式で与えられる。

$$
\bar{u} \leqslant 2 D / R
$$

これによれば，たとえば管径の測定値に $1 \%$ の誤差があ ってもロにおよほすす誤差は約 $0.2 \%$ 以下におさえられ る。

\section{結零}

ガスクロマトグラフ装㬐を使用して分子拡散係数を測 定する際問題となる試料容皘, 検知器内の乱れ, その他 の影变について解折的模討を加え, 分子払散係数を精度 よく求めるために必要な実験条件を明らかにした。

\section{Appendix}

\section{tes? section 長さ $L$ の華出例}

$40^{\circ} \mathrm{C}$ における $\mathrm{CH}_{4}-\mathrm{N}_{2}$ 系の分子拡敬係数を約 $0.2 \%$ の精度 で求めるのに必要な test section の長さを求める。ただ test section の半径 $0.2 \mathrm{~cm}$, 試料注入量 $0.2 \mathrm{cc}$, 注入器容積 は $0.25 \mathrm{cc}$, 椧知器内容稓は $0.2 \mathrm{cc}$ とする。また検知器および 試料注入器内の分散係数々 test section のそれとの比をそれ ぞれ $a=5, b=2$ であると仮定する。

\section{苏出法}

この系の $D$ を約 $0.3 \mathrm{~cm}^{2} / \mathrm{sec}$ と仮定すれば，最通流速籍用 として Eq.(31) より, $\tilde{u}<2 D / R=2 \times 0.3 / 0.2=3 \mathrm{~cm} / \mathrm{sec}$ と与

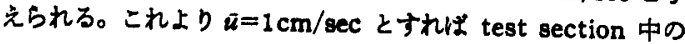




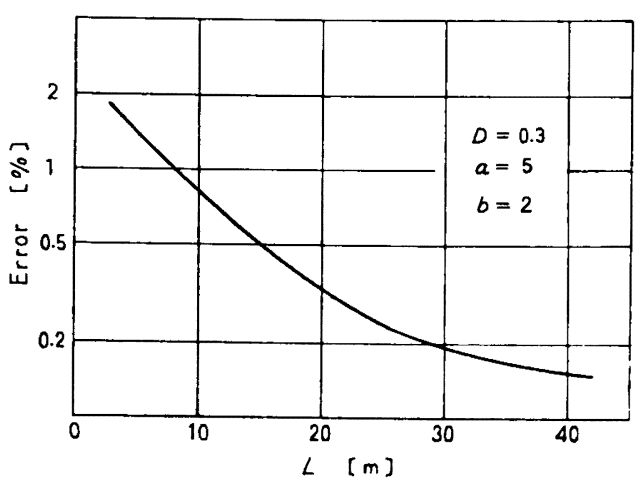

Fig. 6 Relationship between the experimental error and pipe length for $D=0.3, a=5$, and $b=2$

分散保数は Eq.(3) より $E \neq 0.3 \mathrm{~cm}^{2} / \mathrm{sec}$ と決むる。始めに最 む大きい誤差の原因と考えられる入口，出口の乱れの影諠を調 ベろ。 parameter $X_{i}, X_{0}$ は定侾により

$$
X_{i}=0.25 / \pi R^{2} L \div 2 / L, X_{0}=0.2 / \pi R^{2} L \div 1.7 / L
$$

ここで $L$ を通当に仮定して， $X_{i} ， X_{0}$ を求め Fig. 5 により infinite tube とみなした場合の謂差が $0.2 \%$ 以下になる $L$ を決 めればよい。ここでは $L=40 \mathrm{~m}$ と仮定すれば， $\alpha=E / \bar{u} L=7.5$ $\times 10^{-5}, X_{i}=5 \times 10^{-4}, X_{0}=4.3 \times 10^{-4}$ となるので Fig. 5 上り 誈差は約 $0.15 \%$ となり，この条件は満足されていることがわ かる。

次に $L=40 \mathrm{~m}$ として試料容程の影整をみてみる。即ち試料の 幅 $\times 10^{-5}=5.7$ となり，従って Fig. 3 より正規分布とみなした培 合の㽬差はほとんど零となる。

以上のことから test section として必要な長さの目安とし $\tau L \div 40 \mathrm{~m}$ と与えられる。

しし上と同じ条件のもとで，要求精度と管長との関保の大略 を四示すると Fig.6のようになる。

\section{Discussion}

\section{[为 疑]}

分子拡散係数が簡単にまた粮度よく求められることが明らか にされ，またその精度についての娭討が出来ることの明らかに されたことは意義あることと思われます。次の上5な点につき ご意見をお闍かせ下さい。

a) Appendix 中の定数 $\boldsymbol{a}, \boldsymbol{b}$ は普通の装目の値と考えてよ いでしようか。

b）この手法が高压における拡散保数の测定にも利用出来る と, 高圧における $D$ についてはまた不明の点む多いと思われま すので，非常に有意思われますか，その可能性については どら考えられますか。

(編集委貣会)

\section{[回答]}

a）一般に $a, b$ は流速, 管径, とくに使用する検知器の形に よって左右されます。検知器の形は各メーカーによっても異な るし, ここにあげたすのは当研究室における試作品でありまし て，この点はたして標灣といえるかどらかかりません。

b）高殴における $D$ の測定に対する迹用性についてとのこと ですが,ここでは tube を使用していることから，その点では 照合によってはかなりの高圧迄圧力をあげることは不可能では ありません。しかし $D$ の湘定となると次の点から問題が生じま す。即ちここでは Eq.(3)における $E$ を実測して，それより $D$ を求めております。その場合本文 3 節にる述へた事柄から. Eq. （3）の左辺第 2 項が第 1 項の $10 \%$ 以内であるよ5な流速がのそ

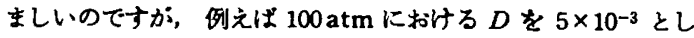
ますと Eq.(31) から

$$
\vec{u} \leqslant 5 \times 10^{-2} \mathrm{~cm} / \mathrm{sec}(R=0.2 \mathrm{~cm} \text { として })
$$

となります。るしかかる流速を高い pressure drop のもとに 長時間一定に保つとなると，その調節は容易なことではありま せん。また一般に换知器も流速が $0.5 \mathrm{~cm} / \mathrm{sec}$ 以下になると原 因不明の外乱がり elution curve に再現性がみられなくな

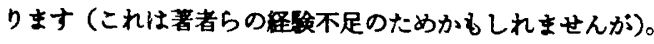

一方流速をそれはどおとさずにDを决定しようとすれば，管 径の决定が大きな問題となってまいります。長さが数メートル あるいは数十メートルとなりますと，均一な管径の tube をい かにして作るか、またその check をいかにするか凮题が生じ ます。

(著者ら)

\section{Nomenclature}
$a: \alpha_{d} / \alpha$
[-]
$b: \alpha_{1} / \alpha$
$C$ : point concentration
[-]
$C_{m}$ : average concentration
$\left[\mathrm{mole} / \mathrm{cm}^{3}\right]$
$D$ : molecular diffusion coefficient
$\left[\mathrm{cm}^{2} / \mathrm{sec}\right]$
$E$ : effective axial dispersion coefficient
$l$ : mixing length
$\left[\mathrm{cm}^{2} / \mathrm{sec}\right]$
$l_{i}$ : width of injected sample gas
[cm]
$L$ : length of the tube
[cm]
$r$ : radial distance
[cm]
[cm]
$R$ : radius.of the tube
[cm]
$s$ : parameter of Laplace transformation [-]
$t: \bar{u} \theta / L$
$[-]$
$t$ : mean residence time (Eq.(23))

$\boldsymbol{u}$ : point velocity

$\bar{u}$ : average velocity

$x$ : axial distance

$X: x / L$

$X_{d}$ : measurement point

$\alpha: E / \bar{u} L$

$\beta: l_{t} / L$

$\theta:$ time

$\check{\theta}$ : mean residence time

$\sigma^{2}$ : variance of residence time

Subscripts

$d$ : refers to detective point

$f:$ refers to fore part of input section

$i$ : refers to input section

0 : refers to after part of detective section [cm/sec] $[\mathrm{cm} / \mathrm{sec}]$ [cm] $[-]$ $[-]$ [-] [-] [sec] [sec] [-] 


\section{Literature cited}

1) Ananthakrishnan, V, W.N. Gill and A.J. Barduhn: $A$. I. Ch. E. Journal, 11, 1063 (1965)

2) Arai, K.: Master thesis of Tohoku Univ. (1967)

3) Arai, K., S. Saito and S. Maeda: Kagaku Kōgaku, 31, 25 (1967)

1) Aris, R.: Proc. Roy. Soc., A235, 67 (1956)

5) Aris, R.: Chem. Eng. Sci., 11, 194 (1959)

6) Aris, R.: ibid, 2, 266 (1959)

7) Bischoff, K. B.: Chem. Eng. Sci, 12, 69 (1960)

8) Bischoff, K. B. and O. Levenspiel: Chem. Eng. Sci., 17, 245 (1962)

9) Chang, G. T.: Doctor thesis of Rice Univ. (1966)

10) Evans, E.V. and C. N. Kenney: Proc. Roy. Soc, A284, 540 (1965)

11) Giddings, J.C. and S. L. Seager: J. Chem. Phys., 33, 1579

(1960)

12) Giddings, J.C. and S. L. Seager: ibid., 35, 2242 (1961)

13) Giddings, J.C. and S. L. Seager: Ind. Eng. Chem. Fundamentals, 1, 277 (1962)

14) Giddings, J.C., S. L. Seager and L. R. Geertson: J. Chem. Eng. Data, 8, 168 (1963)

15) Kramers, H.: Chem. Eng. Sci., 19, 77 (1964)

16) Levenspiel, O. and W.K. Smith: Chem. Eng. Sci, 6, 227 (1957)

17) Taylor, G. I.: Proc. Roy. Soc.London, A219, 186 (1953)

18) Taylor, G. I.: ibid., A223, 446 (1954)

19) Taylor, G. I.: ibid., A225, 473 (1954)

20) Turner, G. A.: Chem. Eng. Sci., 7, 156 (1958)

21) Van der Laan, E. Th.: ibid., 7, 187 (1957)

22) Wehner, J.F. and R. H. Wilhelm : ibid., 6, 89 (1956)

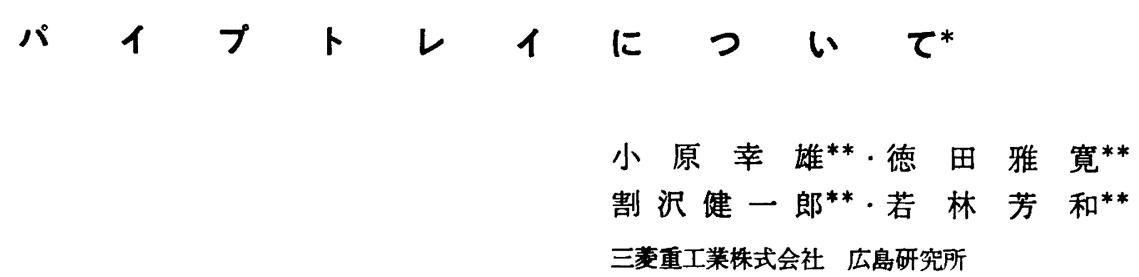

粕容

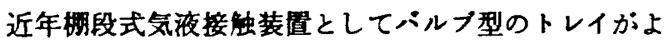
く用いられる。これはバルブ型のトレイが安定性や処理 能力に怙いてハブルキ+ップトレイやシーブトレイに比 べて秀れているといわれているためであろう。本報では 長いスリットの上にパルブとして小さなパイブを誡せた トレイ（パイフトレレ）を用い水一空気による流動試 叙、ベンぜンートルエン混合物による蒸留試験を行ない 压損失と効率について実䜽した。なお比校のためにバブ ルキャップトレイ, シーブトレイ, バルフトレイについ ても実験した。

\section{1. 実験装百と操作}

\section{$1 \cdot 1$ 压损失を测定した装昷}

実験装置を Fig. 1 亿示す。塔はフクリル製で内径 500 $\mathrm{mm}$ である。段間隔が $400 \mathrm{~mm}$ のときは 2 段で, $200 \mathrm{~mm}$ のときは 3 段で試験した。棚板はフルミ板で板厚は 2

- <Performance of Pipe Tray> Received on August 8, 1967

* Sachio Kohara, Masahiro Tokuda, Ken-ichiro Warisawa, Yoshikazu Wakabayashi, (Mitslubishi Heavy Ind. Itd., Hiroshima Technical Institute, Hiroshima) $\mathrm{mm}$ である。トレイの配置図の一例を Fig. 2 に示す(パ イプトレイNo.1の場合で, 溢流部は他のトレイに共

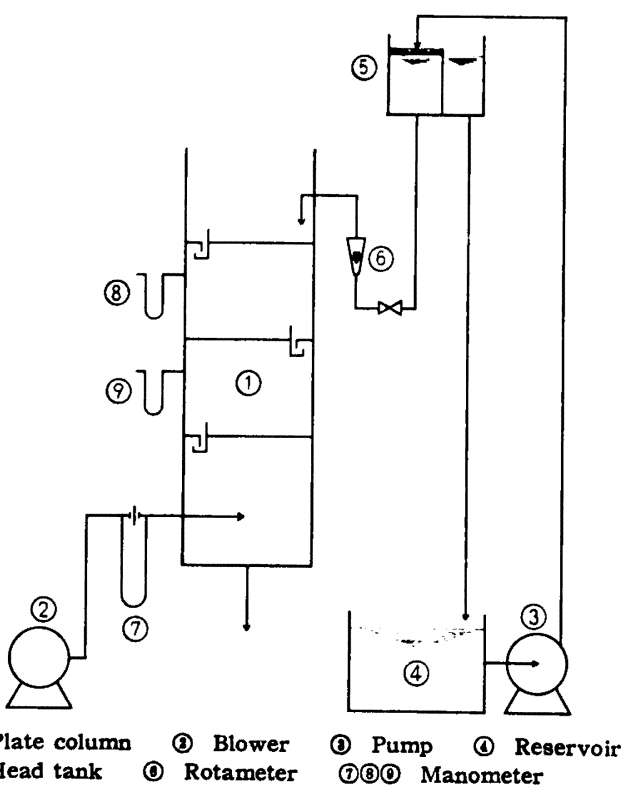

(b) Head tank () Rotameter

Fig. 1 Flow diagram of plate column for pressure drop measurement 


\section{本号の研究誝文要旨}

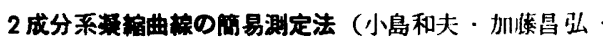

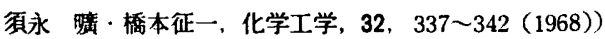

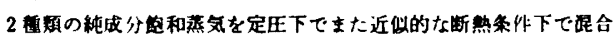

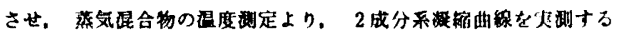

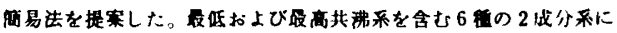

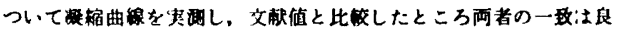

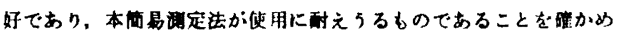

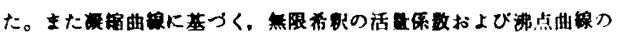
計策式を求め, 娭时を行なった。

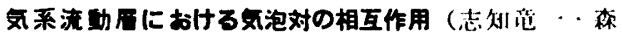

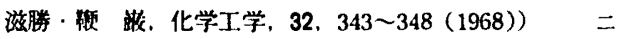

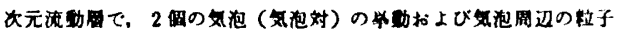

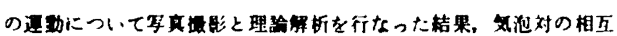

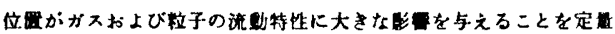

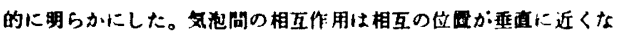

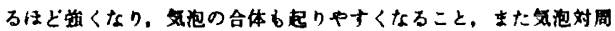

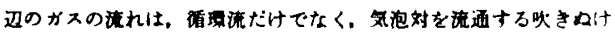
流れが生しることがかった

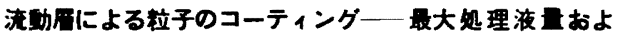
び竝子コーティング胃分布について—（原田和夫 ·藤 旧仁四的，化学工学，32，349 353 (1968)) 流動

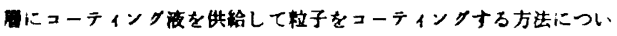

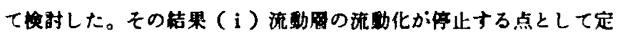

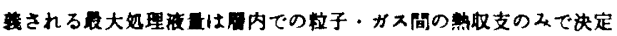

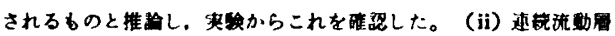

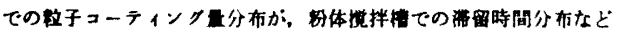

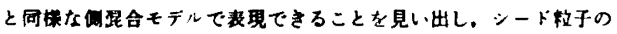

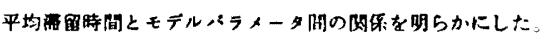

\section{ガスクロマトグラフ装宣による分子苰数係数测定に対す}

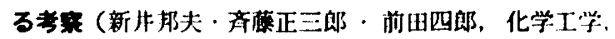

32. 354〜359 (1968)） カスクロマトタラフ表管によって分

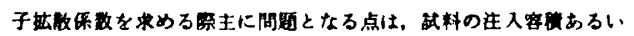

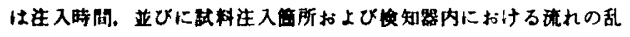
れ等である。ここではこれらの因子が， Sample gas の瞥在時间

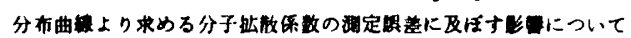

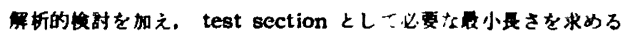
目安を与えた。

パイブトレイについて（小原幸婎・徳田雅宽・割』健一 郎·若林芳和，化学工学, 32，359 364 (1968)) 細長いスッットの上に小さなパイナを铰せた新しい:ルフ型のト レイ(パイトレイ)の王强失と奻事を他の型のトレイ(パフル トッフトレイ、シーフトレイ、スルフトレイ)と比校するための央

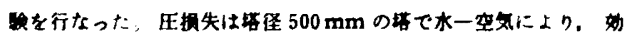

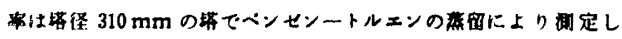

た。実結果

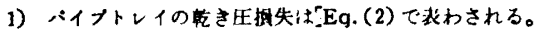

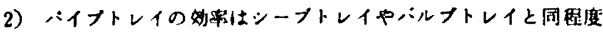
である。

との赫詥を得た。

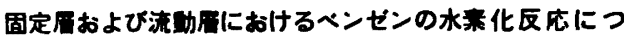
いて (越後谷悦郎·豊田研二・束川 清, 化学工学, 32, 364〜369 (1968)) =ッケル・シリカ蝶によるベンビンの

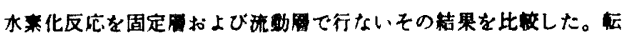

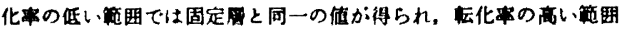

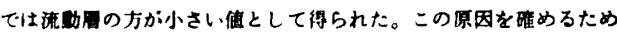

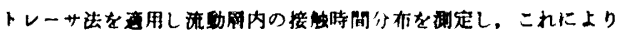
固定周と流動用とのずれを磁明した

混合時間，助力消零およひフローパターンの三つの関这

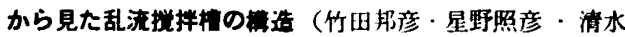
克夫・西烟备男，化学工学，32、369 375 (1968))

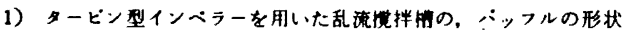

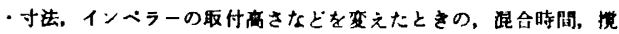
柈トルクおよびフローバターンなどを同一の装卧について湖定し

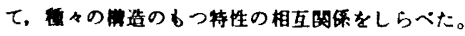

2）フローハターンの新しい分期を提案した。この新分顆によっ て㜔拌トルクの変化とフローハターンの期とが网連つけられる上 ろになった。

多段インベラーによる深い揾の乱流拱洋（竹田邦彦・尘 纾照彦・田口英昭·荫武，化学[学，32，376３81

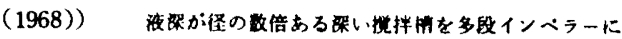

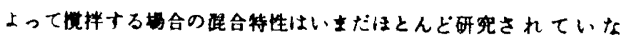
い。本研究恃，これを敷了初の試みとして，インベラーの相対位

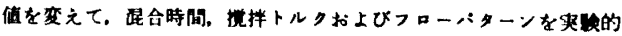

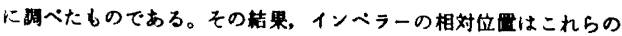

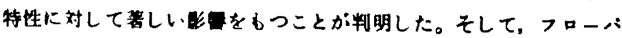

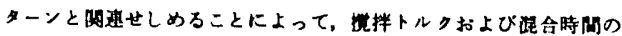
变化を定性的に説明ふけた。

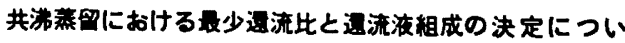
て (頼实正弘·古村尚真, 化学工学, 32, 382 383

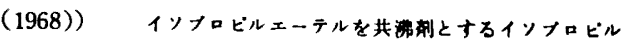
フルコールー水ーインフロビルェーテル系の共焗籍において, 取 少逼流比を決定した。他の系に対して先の文解でのべたと同㥞に，

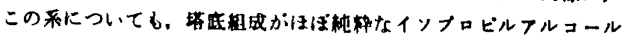

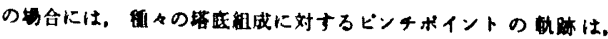

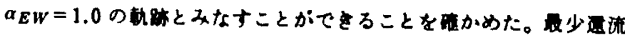
比は $\alpha_{E W}=1.0$ の曲緗と供給就の交点から決定され 6.68 であっ

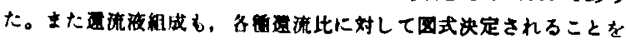
示した。 